\title{
Evaluasi Pelaksanaan Pasca Diklat Pemantapan Pengurus Koperasi di Propinsi Riau
}

\author{
AHMAD FAUZI \\ Badan pengembangan Sumber Daya Manusia (BPSDM) Provinsi Rau \\ Jl. Ronggowarsito No 14 Pekanbaru \\ E-mail : ahmadfauziwi@gmail.com
}

\begin{abstract}
The cooperative becomes the teacher of the nation's economy, this makes the government's attention to efforts to develop cooperatives very large. Cooperative development is inseparable from the role of management, which is where the management of cooperatives becomes an important part. Through the training of strengthening the cooperative management in managing cooperatives carried out by the Human Resources Development Agency (BPSDM), the Province of Rau is expected to achieve future cooperative development efforts. Through this type of qualitative research with resource persons of cooperative management who received training and members of cooperatives in Riau Province and the data was taken using interviews and analyzed qualitatively, the results of the research showed that after the education and training of the cooperative management was established, the optimal period of expected changes to the management of the cooperative itself. This is due to, among other things: the seriousness of the training participants in the training, as well as the factor of the resource persons who are less experienced in carrying out cooperatives and also the cooperative management factors that participate in training not the policy makers. Post-training evaluation efforts need to be given to training participants so that the results of the training can be guaranteed in the future.
\end{abstract}

Keywords: Evaluation, Diklat, Consolidation of Cooperative Managers

Koperasi merupakan suatu perkumpulan yang beranggotakan orang-orang atau badan-badan yang memberikan kebebasan masuk dan keluar sebagai anggota dengan bekerjasama secara kekeluargaan sehingga tidak ada paksaan dalam menjadi bagian dari koperasi tersebut.

Koperasi mempunyai peranan yang cukup besar dalam menyusun usaha bersama dari orang-orang yang mempunyai kemampuan ekonomi terbatas. Usaha ini bertujuan untuk memenuhi kebutuhan yang dirasakan bersama, yang pada akhirnya mengangkat harga diri, meningkatkan kedudukan, serta kemampuan untuk mempertahankan diri dan membebaskan diri dari kesulitan.

Koperasi merupakan salah satu bagian penting dari Manajemen Koperasi, sedangkan manajemen merupakan salah satu bagian penting dari organisasi. Pentingnya Manajemen Koperasi adalah berhasil tidaknya koperasi sangat tergantung dari mutu koperasi dalam bidang manajemenya. Apabila manajemen koperasinya bagus maka besar kemungkinan koperasi akan maju dan dapat mengantisipasi, meminimalisasi kerugian dan masalah yang ada pada koperasi. Akan tetapi jika manajemenya jelek maka koperasi akan mudah terancam dengan masalah-masalah yang muncul, baik masalah yang besar maupun masalah kecil akan berpengaruh buruk bagi koperasi dan mengalami kemunduran dan pada akhirnya akan mengalami kebangkrutan bagi koperasi.

Keberadaan koperasi sekarang ini masih diperhitungkan oleh berbagai pihak diantaranya pemerintah dan masyarakat. Meskipun demikian, koperasi tetap eksis berdiri di tengah kondisi krisis perekonomian Indonesia. Selain itu koperasi juga berkembang di berbagai wilayah Indonesia disaat banyaknya persaingan badan usaha yang beroperasi Koperasi berkembang dengan memperluas kegiatan usahanya dalam berbagai bidang, 
diantaranya dalam bidang produksi, pendistribusian barang dan jasa, jasa simpan pinjam, kerajinan hasil karya masyarakat. Untuk itu agarpengelolaan berjalan dengan baik, koperasi perlu memperhatikan pelayanan yang prima kepada anggota. Selain pelayanan, untuk meningkatkan pertisipasi anggota dibutuhkan kinerja pengurus koperasi. Yang tidak kalah pentingnya demi mewujudkan keberhasilan koperasi dibutuhkannya motivasi berkoperasi. Pelayanan, kinerja pengurus koperasi dan motivasi berkoperasi berpengaruh secara positif terhadap partisipasi anggota. Dengan aktifnya partisipasi anggota diharapkan dapat memberikan inspirasi yang membangun terhadap kegiatan usaha yang dilakukan dalam pencapaian tujuan koperasi. Berkembang tidaknya sebuah koperasi dipengaruhi oleh Pengurus koperasi itu sendiri

Pengurus koperasi adalah pengelola koperasi dan usaha koperasi, yang dipilih dari dan oleh anggota koperasi dalam rapat anggota Dengan demikian maksud dari kepemimpinan pengurus koperasi adalah upaya yang dilakukan jajaran pengurus koperasi selaku pengelola koperasi dalam mempengaruhi anggota-anggota dan karyawan koperasi, sehingga mereka akan berusaha mencapai tujuan organisasi dengan kemauan dan antusias.

Pendidikan dan pelatihan sebagai bentuk usaha nyata yang dilakukan untuk meningkatkan kemampuan, dimana upaya yang dilakukan oleh pemerintah propinsi Riau dalam rangka memantapkan pengelolaan koperasi oleh pengurus koperasi di daerah ini menjadi bagian yang penting. Seakan pelaksanaannya berjalan berhasil karena dilihat dari pelaksanaan saat diklat, dimana peserta Diklat baik diklat pra jabatan maupun diklat pemantapan pengurus koperasi bagi pengurus koperasi dalam jabatan mengenakan seragam diklat atasan putih, bawahan hitam, dasi hitam dan sepatu hitam dengan atribut lengkap yang terdiri dari KORPRI, papan nama dan tanda peserta diklat. Peserta diklat juga datang tepat waktu serta mengikuti diklat sesuai jadwal yang telah ditetapkan. Apabila peserta melanggar ketentuan yang telah ditetapkan, maka peserta diklat harus menerima sanksi yang telah ditetapkan bersama sesuai dengan tingkat kesalahan yang dilakukan.

Materi diklat pemantapan pengurus koperasi bagi pengurus koperasi berbeda untuk setiap jenis diklat yang diikuti oleh PNS. Materi diklat pra jabatan untuk semua golongan sesuai dengan kurikulum yang telah ditetapkan oleh LAN (Lembaga Administrasi Negara). Materi tersebut telah disusun dalam modul pendidikan dan pelatihan prajabatan untuk setiap golongan. Sedangkan materi diklat dalam jabatan untuk diklatpim disesuaikan dengan jenjang struktural eselon di setiap SKPD dan materi untuk diklat fungsional serta diklat tehnis lebih mengarah ke tugas pokok dan fungsi PNS di masing masing institusi. Lama pelaksanaan diklat prajabatan sesuai dengan golongan masing - masing pegawai.

Diklat prajabatan untuk golongan III dilaksanakan selama 3 minggu, golongan II selama 2 minggu dan 1 minggu untuk golongan I. Sedangkan diklatpim pemantapan pengurus koperasi bagi pengurus koperasi untuk jenjang eselon rata - rata dilaksanakan selama 3 bulan dan untuk diklat fungsional dilaksanakan selama 10 hari sesuai dengan kurikulum.

Metode yang digunakan dalam diklat PNS mengenai pemantapan pengurus koperasi bagi pengurus koperasi adalah metode belajar mengajar andragogi atau metode belajar orang dewasa. Metode tersebut meliputi metode ceramah, tanya jawab, diskusi, presentasi dan simulasi. Metode presentasi serta simulasi lebih sering digunakan dalam diklat dan setiap peserta diklat berhak memberikan pendapat dalam setiap diskusi yang dilaksanakan di dalam kelas. Tujuan dari penggunaan metode ini 
adalah untuk lebih meningkatkan peran serta peserta diklat serta menumbuhkan keberanian peserta diklat untuk menyampaiakan pendapat sehingga pada saat kembali ke instansi bisa memberikan nilai lebih bagi instansi tersebut.

Instruktur diklat PNS adalah Widya Iswara yang telah ditunjuk untuk pemantapan pengurus koperasi bagi pengurus koperasi juga mempunyai teknik icebreaking yang bagus sehingga peserta diklat tidak jenuh ada di dalam kelas selama mengikuti diklat. Di setiap akhir kelas, peserta diminta untuk memberikan penilaian terhadap cara penyampaian materi setiap pemantapan pengurus koperasi bagi pengurus koperasi. Penilaian ini merupakan bentuk evaluasi secara keseluruhan terhadap pemantapan pengurus koperasi bagi pengurus koperasi untuk mencapai tujuan diklat yang telah ditentukan.

Semua diklat yang dilaksanakan oleh PNS diawali deng pre test dan diakhiri dengan post test. Tujuan dari pre test dan post test ini bertujuan untuk melihat seberapa jauh daya serap peserta diklat terhadap materi yang telah diberikan. Pendidikan dan pelatihan (Diklat)) adalah pelatihan danpengembangan yang mengacu pada fungsi organisasi yang diarahkan untuk memastikan supaya distribusi dari individu-individu dan kelompok kelompok dimaksimalkan melalui pengembangan pengetahuan, keterampilan, dan sikap yang tepat. Sehingga pada dasarnya pendidikan dan pelatihan merupakan suatu upaya untuk memaksimalkan kompetensi tiap masingmasing individu maupun sebuah kelompok dalam sebuah organisasi. Dengan demikian, penting bagi setiap Satuan Perangkat Kerja Pemerintah Daerah (SKPD) untuk selalu meningkatkan kualitas pegawai sesuai dengan tugas pokok dan fungsinya masing - masing.

Sampai saaat ini, Badan pengembangan Sumber Daya manusia Provinsi Riau telah melakukan upaya upaya peningkatan kualitas dan kompetensi pegawai melalui Program Pendidikan dan pelatihan Formal serta Program Peningkatan Kompetensi Pegawai. Namun, keterbatasan anggaran dana di Provinsi dan Kabupaten menjadi pemicu terhambatnya pelaksanaan program tersebut. Dengan demikian, perlu adanya advokasi ke bupati untuk mengalokasikan anggaran dalam rangka peningkatan kualitas pegawai baik melalui tugas belajar, diklat maupun seminar sesuai dengan jabatan yang ada di Badan pengembangan Sumber Daya manusia Provinsi Riau.

Namun berbagai persoalan yang ditemukan di lapangan berkaitan mengenai hasil diklat dalam memantapkan kepengurusan koperasi masih belum optimal. Data lapangan menunjukkan bahwa masih belum optimalnya laporan rapat anggota tahunan yang dilakukan pengurus, partisipasi anggota dalam kepengurusan koperasi yang rendah dan anggota yang menolak laporan pertanggungjawaban pengurus koperasi dan lebih diperparah dengan koperasi yang mengalami penurunan omzet. Hal ini diperkuat dengan data selama tahun 2011 sampai dengan 2015 dan di tahun 2015 koperasi aktif mencapai $71,6 \%$ sedangkan sisanya adalah tidak aktif. Sedangkan koperasi yang mengadakan RAT hanya mencapai $38,1 \%$ lebih banyak yang tidak melaksanakan RAT atau sebanyak 61,9\%. (Sumber: Kementrian Koperasi dan UMKM, 2016)

Tinjauan umum tentang Koperasi dimulai dari dasar hukum koperasi adalah Pasal 33 ayat (1) Undang-Undang Dasar Negara Republik Indonesia 1945 (UUD N RI 1945) dan Undang-Undang Nomor 25 Tahun 1992 Tentang Perkoperasian. Merujuk pada Undang-Undang Republik Indonesia Nomor 25 Tahun 1992 tentang Perkoperasiaan maka tersirat suatu harapan bahwa Koperasi bertujuan meningkatkan kesejahteraan anggota pada khususnya dan masyarakat pada umumnya.

Berangkat dari persoalan yang menjadi fenomena dan penting 
mendapatkan perhatian antara lain berkaitan pertanyaan bagaimana hasil evaluasi berkaitan dengan pasca diberikannya diklat pemantapan pengurus koperasi dalam menumbuhkembangkan koperasi di Propinsi Riau.

\section{METODE}

Melalui jenis penelitian kualitatif dengan narasumber pengurus koperasi yang mendapatkan pelatihan dan juga anggota koperasi di Propinsi Riau dan data diambil dengan menggunakan wawancara serta dianalisis secara kualitatif.

\section{HASIL}

Berdasarkan hasil penelitian bahwa setelah dilakukannya pendidikan dan pelatihan pemantapan pengurus koperasi yakni dalam masa satu tahun berjalan belum optimal perubahan yang diharapkan terhadap kepengurusan koperasi itu sendiri. Dalam praktek lapangan pengurus masih mengacu pada kebiasaan sebelum mendapatkan pelatihan dan hal ini dilakukan secara terus menerus. Pengurus masih menganggap bahwa pelatihan yang diberikan pemerintah bukan dalam upaya mencapai keberhasilan koperasi untuk mengurus koperasinya.

Fakta lain juga menunjukkan bahwa kepengurusan koperasi adanya intrik mencari keuntungan dan kekuasaan. Dimana pengurus bukan murni untuk mengurus koperasi demi kesejahteraan anggota, melainkan mereka mengurus untuk keinginannya mendapatkan kekuasaan dan status sosial di masyarakat dan juga ingin mendapatkan keuntungan berupa uang.

Berdasarkan hasil wawancara yang dilakukan di lapangan diperoleh informasi bahwa terdapat beberapa faktor yang menyebabkan kondisi demian antara lain:

\section{Faktor kesungguhan peserta pelatihan dalam mengikuti pelatihan}

Pelatihan yang dilaksanakan lebih kurang 10 hari kerja masih belum optimal diikuti oleh peserta, dimana peserta terkadang yang kurang serius mengikuti pelatihan hal ini ditandai dari tanggapan peserta mengenai pelatihan semacam ceritacerita yang kurang memberikan manfaat pada pengurusan koperasi di lapangan. Sikap dari peserta ini menimbulkan beberapa dampak antara lain kesungguhan kepada peserta mendengarkan materi pelatihan yang diebrikan dan juga mereka kurang yakin akan materi yang diberikan kepadanya.

\section{Faktor narasumber yang kurang berpengalaman dalam mengusur koperasi}

Kurang berpengalamannya narasumber dalam kepengurusan koperasi yang berhasil menyebabkan peserta kurang percaya terhadap materi yang diberikan. Adanya anggapan peserta bahwa: "entah iye entah tidak". Anggapan ini yang memiliki makna ragu terhadap materi yang diberikan pihak narasumber. Narasumber dari kalangan pemerintah kurang memahami kondisi nyata kepengurusan perkoperasian, sehingga penjelasan terkesan mengambang dan juga menjadikan membingungkan dan juga tidak memberikan solusi. Sedangkan pemateri dari kalangan perguruan tinggi (akademisi) terlalu teoritis, menjadikan peserta sulit memahami. Karena rata-rata pendidikan pengurus koperasi berpendidikan SMP dan SMA.

Faktor pengurus koperasi yang ikut pelatihan bukan pengambil kebijakan.

Pengurus yang dikirim mengikuti pelatihan bukan pengurus inti dan pengambil kebijakan. Kemudian pasca diberikannya pelatihan tidak ada sosialisasi kepada pengurus yang ada di lapangan. Hal ini menyebabkan apa yang diperoleh saat pelatihan tidak sampai kepada kepengurusan yang ada.

Pengurus inti kurang tertarik dengan bahasan yang diberikan dan juga membuat materi yang tidak bermanfaat dalam usaha memantapkan pengurusan koperasi. Sikap ini menjadi bagian penting dalam memastikan apa yang dihasilkan dalam pelatihan diterapkan di lapangan dalam 
mengurus koperasi. Juga berkaitan dengan masalah efektifitas materi pelatihan yang diberikan sampai kepada pengurus dalam mengurus koperasi juga dinilai masih belum optimal.

\section{PEMBAHASAN}

Berdasarkan hasil penelitian menunjukkan bahwa adanya fakta menunjukkan belum adanya hasil yang optimal dari pelatihan yang diberikan kepada pengurus. Faktor kesungguhan peserta pelatihan menjadi salah satu penyebab kurang efektinya pelatihan yang diterima peserta.

Hal ini juga sesuai dengan apa yang dikatakan Hadipermana, O. (2009) bahwa berbagai upaya yang menarik peserta pelatihan dari pemateri menjadi bagian pentig dalam memotivasi peserta untuk mengikuti pelatihan.

Kemudian juga faktor dari pemateri pelatihan, menurut Apizal, A. (1998) menunjukkan keefektifan pelatihan pengetahuan manajer tentang manajemen sebesar 67,71 \% (kurang efektif) dan keefektifan pelatihan kinerja manajer sebesar $68,20 \%$ (kurang efektif), metode penyampaian materi pelatihan kurang tepat. Pengurus, pembina, pengawas, dan pembina yang menjalankan fungsi dan tanggung jawab yang baik adalah pengelola yang menjalin koordinasi dengan sesama KUD, aktif mendorong kinerja manajer, dan bekerja secara mandiri.

Disampaikan oleh Setiawan, W. H. (2013) bahwa Ketatalaksanaan diklat: kehadiran peserta, mekanisme registrasi peserta mulai dari peserta datang sampai penyerahan kunci kamar inap; asrama: kebersihan kamar asrama dan lingkungan, kebersihan kamar mandi/WC asrama, kebersihan air kamar mandi/WC, penerangan dan kelengkapan kamar, dan pelayanan petugas asrama. Konsumsi dan ruang makan: variasi menu makanan dan menu rehat, kebersihan makanan, kebersihan peralatan makan dan minum, kebersihan ruang makan, dan pelayanan petugas ruang makan. Prasarana lainnya, meliputi: kebersihan ruang kelas dan perlengkapannya, alat bantu latihan, penyajian bahan serahan/modul, sarana ibadah, sarana olahraga, pelayanan toko/foto copy dan wartel, ketersediaan kebutuhan peserta yang bukan kewajiban balai diklat, dan fasilitas pelayanan perpustakaan. Kesiapan tatalaksana diklat, meliputi pengelolaan: pembukaan diklat, widyaiswara, warga belajar diklat, tempat/gedung, ruang kelas, penunjang proses pembelajaran, asrama, dan konsumsi. Ketatalaksanaan diklat di atas termasuk kegiatan persiapan ketatausahaan atau non-akademik. Skenario diklat dasardasar perkoperasian, widyaiswara memiliki skenario yang jelas dan terarah khususnya dalam perancangan diklat yang bersifat change of behavior dan problem solving guna pelaksanaan diklat berjalan sesuai dengan tujuan. Dalam skenario, diklat menggunakan metode ceramah, tanya jawab, brainstorming, diskusi, dan praktik dengan berbagai metode di atas widyaiswara menyalurkan ilmu pengetahuan agar peserta diklat menguasai knowledge,

skill, dan attitude karena sasaran peserta memang seluruhnya adalah orang dewasa. Peningkatan kemampuan diklat tidak dapat dipisahkan dari peranan widyaiswara sebagai pengajar diklat. Widyaiswara harus mengerti bagaimana menciptakan situasi dan lingkungan belajar bagi setiap orang agar terangsang untuk memperoleh sesuatu, manfaat fungsi alat peraga agar membantu memperlancar tugasnya, serta menguasai keterampilan manajemen dan administrasi guna memahami hubungan antar-pribadi khususnya dalam dinamika kelompok. Metode yang diterapkan terkait dengan seluruh proses diklat, setiap widyaiswara memiliki gaya-gaya pembelajaran tersendiri untuk meningkatkan kemampuan dasardasar perkoperasian peserta diklat, selain itu kemampuan masing-masing widyaiswara disesuaikan dengan materi bidang yang digelutinya. Pesan pembelajaran tidak akan dapat diterima dengan baik oleh peserta diklat, jika pengajar, kurang menguasai metode pembelajaran.

Berbagai metode yang diterapkan 
seperti: ceramah dan tanya jawab, brainstorming atau curah pendapat dan diskusi, serta penugasan dan praktik, dapat diterapkan, namun terdapat beberapa faktor yang mempengaruhi penggunaan metode seperti: kemampuan personal widyaiswara dan alokasi waktu yang diberikan. Keberadaan metode dalam diklat perkoperasian merujuk pada prinsip andragogi, dengan sedikit variasi berupa inovasi pembelajaran model pembelajaran partisipatori seperti diskusi kelompok atau brainstorming.

Juga berkaitan dengan masalah peserta pelatihan disampaikan oleh Badhowi, I. (2018) bahwa terdapat pengaruh yang signifikan antara motivasi belajar dan pengalaman kerja peserta terhadap ketercapaian tujuan pelatihan RK/RAPB Koperasi yaitu dengan taraf signifikansi sebesar 0,000 dengan nilai $\mathrm{F}_{\text {hitung }} 24,828>$ $\mathrm{F}_{\text {tabel }}$ 3,34 yang menyatakan bahwa hipotesis mayor $\mathrm{H}_{1}$ diterima dengan pernyataan terdapat pengaruh yang signifikan antara motivasi belajar dan pengalaman kerja peserta terhadap ketercapaian tujuan pelatihan RK/RAPB Koperasi.

\section{SIMPULAN}

Setelah dilakukannya pendidikan dan pelatihan pemantapan pengurus koperasi yakni dalam masa satu tahun berjalan belum optimal perubahan yang diharapkan terhadap kepengurusan koperasi itu sendiri. Hal ini disebabkan antara lain: faktor kesungguhan peserta pelatihan dalam mengikuti pelatihan, juga faktor narasumber yang kurang berpengalaman dalam mengusur koperasi dan juga faktor pengurus koperasi yang ikut pelatihan bukan pengambil kebijakan.

Perlu upaya evaluasi pasca pelatihan yang diberikan kepada peserta pelatihan sehingga hasil pelatihan dapat dijamin keberhasilannya di masa depan.

\section{DAFTAR RUJUKAN}

Apizal, A. 1998. Keefektifan Pelatihan Manajemen Koperasi bagu Manajer KUD di Kabupaten Kerinci. Jurnal Penelitian dan Evaluasi Pendidikan, 1(1).

Badhowi, I. (2018). Pengaruh Motivasi Belajar Dan Pengalaman Kerja Peserta Terhadap Ketercapaian Tujuan Pelatihan Rk/Rapb Koperasi. Jurnal Pendidikan Nonformal, 10(1), 47-54.

Hadipermana, O. (2009). Model Kewirausahaan Koperasi dan Implikasinya terhadap Program Pelatihan Kewirausahaan. Jurnal Pendidikan Luar Sekolah, 4(2).

Setiawan, W. H. (2013). Ketatalaksanaan dan Strategi Pendidikan dan Latihan Dasar-dasar Perkoperasian di UPT Diklat Koperasi dan UMKM Jawa Timur. SKRIPSI Jurusan Pendidikan Luar SekolahFakultas Ilmu Pendidikan UM. 